\title{
Purinergic modulation of microglial cell activation
}

\author{
Beáta Sperlágh $\cdot$ Peter Illes
}

Received: 13 January 2006 / Accepted: 13 January 2006 / Published online: 19 December 2006

(C) Springer Science + Business Media B.V. 2006

\begin{abstract}
Microglial cells are resident macrophages in the brain and their activation is an important part of the brain immune response and the pathology of the major CNS diseases. Microglial activation is triggered by pathological signals and is characterized by morphological changes, proliferation, phagocytosis and the secretion of various cytokines and inflammatory mediators, which could be both destructive and protective for the nervous tissue. Purines are one of the most important mediators which regulate different aspects of microglial function. They could be released to the extracellular space from neurons, astrocytes and from the microglia itself, upon physiological neuronal activity and in response to pathological stimuli and cellular damage. Microglial activation is regulated by various subtypes of nucleotide $(\mathrm{P} 2 \mathrm{X}, \mathrm{P} 2 \mathrm{Y})$ and adenosine $\left(\mathrm{A}_{1}\right.$, $A_{2 A}$ and $A_{3}$ ) receptors, which control ionic conductances, membrane potential, gene transcription, the production of inflammatory mediators and cell survival. Among them, the role of $\mathrm{P}_{2} \mathrm{X}_{7}$ receptors is especially well delineated, but $\mathrm{P}_{2} \mathrm{X}_{4}$, various $\mathrm{P} 2 \mathrm{Y}, \mathrm{A}_{1}, \mathrm{~A}_{2 \mathrm{~A}}$ and $\mathrm{A}_{3}$ receptors also powerfully participate in the microglial response. The pathological role of microglial purine receptors has also been demonstrated in disease models; e.g., in ischemia, sclerosis multiplex and neuropathic pain. Due to their upregulation and selective activation under pathological
\end{abstract}

\section{B. Sperlágh}

Department of Pharmacology, Institute of Experimental Medicine,

Hungarian Academy of Sciences,

1450 Budapest, Hungary

P. Illes $(\square)$

Rudolf-Boehm-Institute of Pharmacology and Toxicology,

University of Leipzig,

04107 Leipzig, Germany

e-mail: illp@medizin.uni-leipzig.de conditions, they provide new avenues in the treatment of neurodegenerative and neuroinflammatory illnesses.

Key words adenosine receptors - ATP - microglia . neurodegeneration $\cdot \mathrm{P} 2 \mathrm{X}_{7}$ receptor $\cdot \mathrm{P} 2 \mathrm{Y}$ receptors

$\begin{array}{ll}\text { Abbreviations } \\ \text { AD } & \text { Alzheimer's disease } \\ \text { A } \beta & \text { amyloid- } \beta \text { peptide } \\ \text { APP } & \text { amyloid precursor protein } \\ \text { ALS } & \text { amyotrophic lateral sclerosis } \\ \text { 2-AG } & \text { 2-arachydonoylglycerate } \\ \text { ABC } & \text { ATP binding cassette } \\ \text { LPS } & \text { bacterial lypopolisaccharide } \\ \text { BzATP } & \text { 2', 3'-O-(4-benzoyl-benzoyl)adenosine } \\ & \text { 5'-triphosphate } \\ \text { CNT } & \text { concentrative nucleoside transporter } \\ \text { COX-2 } & \text { cyclooxigenase-2 } \\ \text { E-NTPDase } & \text { ectonucleoside triphosphate diphospho- } \\ & \text { hydrolase } \\ \text { E-NPP } & \text { ecto-nucleotide pyrophophatase } \\ \text { ENT } & \text { equilibrative nucleoside transporter } \\ \text { EAE } & \text { experimental autoimmune encephalomyelitis } \\ \text { ERK } & \text { extracellular signal regulated protein kinase } \\ \text { GFAP } & \text { glial fibrillary acidic protein } \\ \text { iNOS } & \text { inducible nitric oxide synthase } \\ \text { IL-1 } \beta & \text { interleukin-1 } \beta \\ \text { ICE } & \text { interleukin-1 convertase enzyme } \\ \text { IL-6 } & \text { interleukin-6 } \\ \text { MRF-1 } & \text { microglial response factor-1 } \\ \text { MCAO } & \text { middle cerebral artery occlusion } \\ \text { MAPK } & \text { mitogen activated protein kinase } \\ \text { NGF } & \text { nerve growth factor } \\ \text { NO } & \text { nitric oxide } \\ \text { NFAT } & \text { nuclear factor of activated T cells } \\ & \end{array}$




$\begin{array}{ll}\text { PD } & \text { Parkinson's disease } \\ \text { PI3K } & \text { phosphatidylinositol-3'-kinase } \\ \text { PLC } & \begin{array}{l}\text { phospholipase C } \\ \text { pyridoxal-phosphate-6-azophenyl-2',4'- } \\ \text { PPADS }\end{array} \\ \text { disulphonic acid } \\ \text { ROI } & \begin{array}{l}\text { reactive oxygen intermediates } \\ \text { sclerosis multiplex }\end{array}\end{array}$

\section{Introduction}

Microglial cells originate from monocyte/macrophage precursors and are regarded as the major immunocompetent cell type of the nervous system, constituting about $10 \%$ of all cells in the brain. The immune response of the brain is spatially segregated from the peripheral immune response by the blood brain barrier and together with astroglial cells and infiltrating peripheral immune cells, is predominantly executed by microglial cells. Thus, this cell type is rapidly activated in response to pathological signals such as ischemia or bacterial endotoxin and respond with morphological changes transforming the resting ramified microglia to an amoeboid form with phagocytic activity, proliferation and the production of a wide array of inflammatory mediators. Although microglial activation is a highly complex process, consisting of a number of interrelated extra- and intracellular pathways, it is a rather uniform response, which is triggered by any environmental challenge, which affects the functional integrity of the nervous tissue. Therefore, microglial activation is heavily implicated in the pathogenesis of virtually all CNS diseases and the following repair process, including brain and spinal cord injury, stroke, Alzheimer's (AD) and Parkinson's disease (PD), sclerosis multiplex (SM), amyotrophic lateral sclerosis (ALS) and sensory neuropathies. Apart from cytokines, growth factors, and other bioactive substances, purines are one of the most important mediators which regulate and orchestrate various aspects of microglial activation by the interaction of numerous subtypes of adenosine (P1) and nucleotide (P2) receptors.

\section{Purine bioavailability under conditions leading to microglial activation}

The participation of purines in the microglial response presumes their accumulation in the extracellular space upon signals activating microglia. Extracellular purine availability in the nervous system is basically determined by the balance of release, and removal by enzymatic degradation and uptake. Whereas ATP is released per se, adenosine is thought to be generated in the extracellular space as a breakdown product of released ATP, but it could be also released on its own right, depending on the type of stimulus. Since ATP is ubiquitous, all metabolically active cells of the nervous system are able to synthesize ATP, which provides a potential pool for release. Therefore, the cellular source of released purines participating in microglial activation could be any cell type located in contact with microglia, i.e., nerve terminals, astrocytes, endothelial tissue and finally the microglial cells themselves as well. The majority of ATP is formed in the mitochondria by oxidative phosphorylation, which results in approximately $10 \mathrm{~mm}$ ATP concentration in the cytoplasm under normal metabolic conditions. In addition, ATP is also taken up and stored in synaptic vesicles of nerve terminals [1] and astrocytes [2]. On the other hand, the basal intracellular adenosine concentration is much less, in the low micromolar to high nanomolar range, and the majority of adenosine, which is taken up into cells is rapidly reincorporated into ATP stores, or deaminated by adenosine deaminase under normal metabolic conditions [3].

A wide variety of stimuli are known to release ATP and/ or adenosine to the extracellular space, which theoretically could lead to purine levels sufficiently high to activate nucleotide receptors expressed on the surface of microglia (Fig. 1) [1, 3, 4]. Although the stimulation-dependent release of ATP and adenosine upon conventional $[5,6]$ and high frequency [7] neuronal activity is well documented, these stimuli probably result in a spatially restricted, localized increase in extracellular purine levels, which serve the synaptic transmission and the modulation of preand postsynaptic functions within the synaptic cleft. ATPmetabolizing ectoenzymes, present on the nerve terminal membrane, but also on the surface of microglia [8], such as ectoNTPDases, the CD73/ecto-5'-nucleotidase [9] and nucleoside transporters may strongly limit purine availability under these conditions. On the other hand, pathological events such as mechanical or metabolic stress, inflammation, cellular injury or changes in the ionic environment are known also to powerfully stimulate purine release. This might result in a purine-rich extracellular milieu leading to a more widespread activation of receptors reaching also the neighboring or distant cells such as astrocytes and microglia as well. These signals include mechanical $[2,10,11]$ and hypotonic [12] stimuli, hypoxia/hypoglycemia/ischemia and consequent energy deprivation [13-17], inflammatory signals, such as bacterial lypopolisaccharide (LPS) $[18,19]$, concanavalin-A [20], or interleukin-1 $\beta$ (IL-1 $\beta$ ) [21], and cytolysis, which could release purines not only from neurons but also from non-neuronal cells, i.e., from astrocytes, endothelial cells and from the microglia itself. Moreover, nucleotides and nucleosides by themselves may promote further release of purines, by a homo- or heteroexchange mechanism, if they reach relatively high concentration in the extracellular space [22]. 


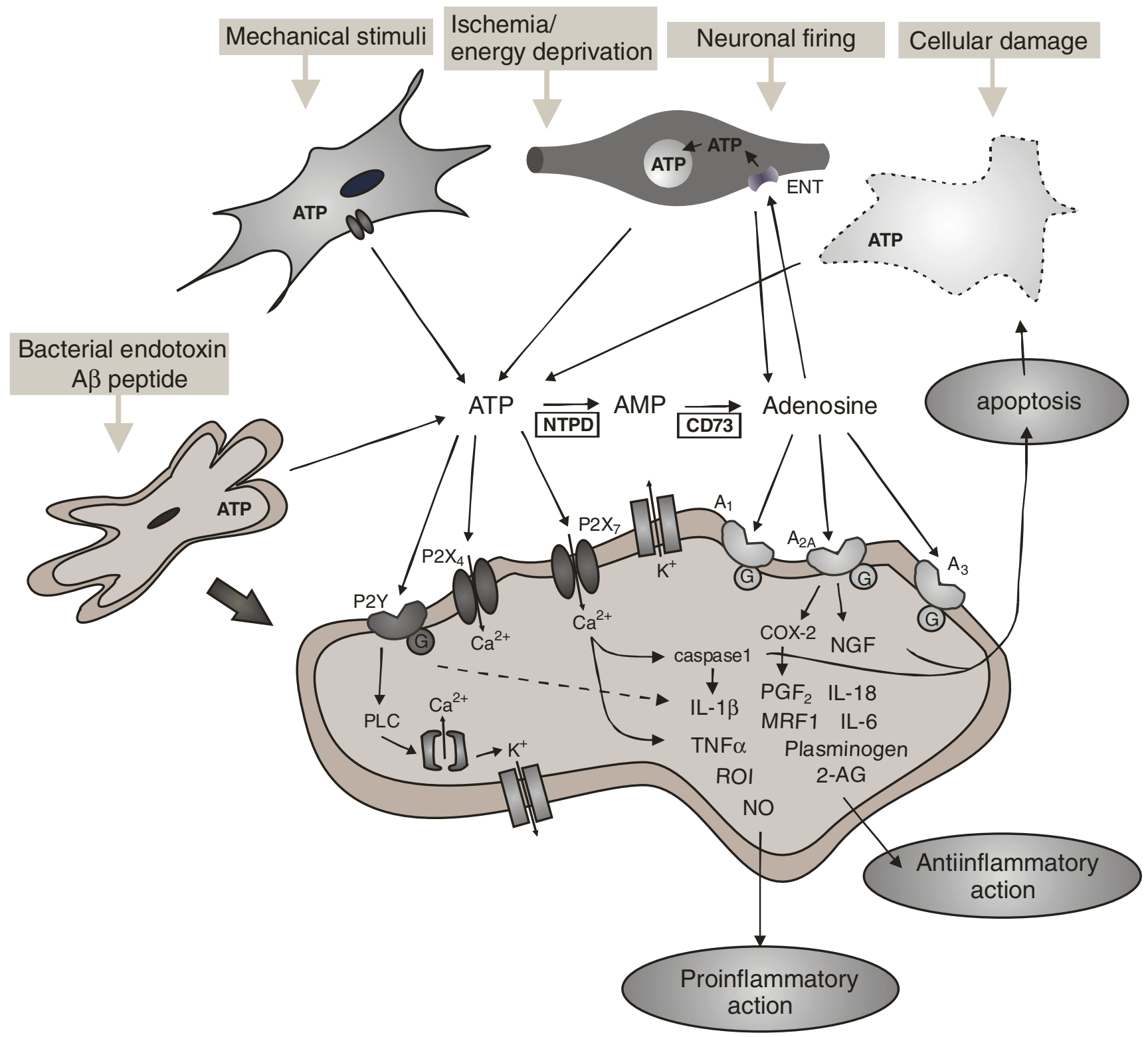

Fig. 1 A summary of purinergic pathways involved in microglial response. Since ATP is ubiquitous, it is present in the cytoplasm of nerve terminals, astrocytes, and the microglia itself. It is released to the extracellular space in response to a wide variety of signals, including neuronal firing, mechanical stimuli, ischemia/energy deprivation, bacterial endotoxin and cellular damage. Adenosine could be either released from cells, or generated from extracellular ATP via breakdown by NTPDase (NTPD) and CD73/5'-nucleotidase $(C D 73)$ enzymes. The action of adenosine is terminated by its uptake into nerve terminals by the equilibrative nucleoside transporter system (ENT), and the same transporters could mediate the release of adenosine under energy deprivation. ATP acts on ionotropic $\mathrm{P}_{2} \mathrm{X}_{7}$ and $\mathrm{P} 2 \mathrm{X}_{4}$ receptors, and also on metabotopic $\mathrm{P} 2 \mathrm{Y}$ receptors, whereas adenosine activates metabotropic $A_{1}, A_{2 A}$ and $A_{3}$ receptors, all present on the surface of activated microglia. Whilst the activation of $\mathrm{P} 2 \mathrm{X}$ receptors triggers an inward cationic current and depolarizes the microglial membrane, the activation of $\mathrm{P} 2 \mathrm{Y}$ receptors is coupled to the $\mathrm{G}$ protein- phospholipase $\mathrm{C}(P L C)$ signal transduction pathway, both resulting in the elevation of intracellular $\mathrm{Ca}^{2+}$. $\mathrm{P} 2 \mathrm{X}$ receptors are involved in the expression, posttranslational processing and secretion of various factors shaping the microglial response-i.e., IL $-1 \beta$, IL-6, IL-18, TNF- $\alpha$, reactive oxygen intermediates (ROI), plasminogen, 2-arachydonoyl glycerate $(2-A G)$, and microglial response factor-1 (MRF-1) -and thereby contribute to both the proinflammatory and antiinflammatory aspects of microglial activation. In addition, $\mathrm{P} 2 \mathrm{X}_{7}$ receptors eventually also mediate apoptosis by caspase 1 activation. The stimulation of $\mathrm{P} 2 \mathrm{Y}$ receptors hyperpolarizes the microglia, via an outward $\mathrm{K}^{+}$conductance and inhibits the production of proinflammatory mediators. Adenosine receptors regulate the proliferation/survival of microglia, COX-2 expression and subsequent secretion of $\mathrm{PGF}_{2}$, and the production of nerve growth factor $(N G F)$. For more details and references, see text. For the sake of clarity, details of intracellular signal transduction and transcriptional changes are not illustrated 
Since ATP is a highly polarized molecule, which cannot pass freely through the cell membrane, it is also of interest to identify the mechanism, whereby it could enter the extracellular space. These include (1) vesicular exocytosis, (2) carrier-mediated release, (3) release through channels and membrane pores, (4) cytolytic release.

(1) Vesicular exocytosis is a prototype mechanism for neurotransmitters to enter the extracellular space, which is expected to be a $\left[\mathrm{Ca}^{2+}\right]_{\mathrm{o}}$-dependent process. Indeed, $\left[\mathrm{Ca}^{2+}\right]_{\mathrm{o}}$-dependent ATP and adenosine release in response to neuronal stimulation appears in many areas of the central and peripheral nervous system (for further references see [1, 3, 4]. Moreover, recent findings indicate that vesicular ATP release could be derived not only from nerve terminals but also from astrocytes [2].

(2) Although specific transporters capable for the transmembrane movement of ATP are yet to be molecularly identified in the nervous system, ABC (ATP binding cassette) proteins have been implicated as ATP transporters $[12,23,24]$ in non-neuronal cells. These transporters are also expressed in glial cells [25] and mediate ATP release upon hypoosmotic challenge $[26,27]$. On the other hand, transmembrane transporters for adenosine and other nucleosides are widely expressed in the nervous system. Specific nucleoside transporters consist of two families: equilibrative transporters (ENT) and concentrative transporters (CNT); the former is driven by the concentration gradient, the latter is driven by the sodium gradient [28, 29]. ENT transporters could carry different nucleosides, including adenosine and inosine, but not nucleotides, across the cell membrane in both directions, and they are regarded as the dominant nucleoside transporters of the brain. Since the intracellular adenosine level under normal metabolic state is in the low micromolar range [3], if the ENT transporter is loaded from the extracellular space by excess adenosine, it mediates adenosine uptake into the nerve terminals. When adenosine is taken up, intracellular adenosine eliminating mechanisms, the adenosine kinase and adenosine deaminase enzymes convert it to AMP and inosine, respectively, thereby maintaining the driving force of the carrier. However, the ENT transporter could also act in a reverse direction under certain circumstances, mediating the release of adenosine into the extracellular space. This could occur during energy deprivation or metabolic distress, when ATP stores are depleted and AMP is generated intracellularly. Cytosolic 5'-nucleotidase, which has a relatively high $\mathrm{K}_{\mathrm{m}}$ for AMP $(1-14 \mu \mathrm{M})$, becomes active under these conditions and accumulates aden- osine intracellularly. This adenosine then flows out to the extracellular space in a transporter-mediated manner $[3,30]$.

(3) Channels and pores are also potential candidates to drive the transmembrane movement of ATP. Connexin hemichannels are gap junction proteins, and their main function is to mediate electrical signaling, but they are also able to release neuroactive substances such as glutamate and ATP [31]. They have been recently identified to mediate ATP release from astrocytes and other non-neuronal cells in response to mechanical stress [32-35].

(4) Although it has only recently received direct experimental proof [36], any kind of cellular injury is generally thought to result in high local ATP concentrations in the extracellular space. In this case the millimolar cytoplasmic ATP is expected to flow out to the extracellular space through the membrane damage.

Apart from release, the other major factor determining purine bioavailability is their removal from the extracellular space by enzymatic degradation and transporters. Several enzyme families are responsible for the extracellular degradation of ATP in the nervous system. The first step of the inactivation of ATP is mediated by the family of ectonucleoside triphosphate diphospho-hydrolases (E-NTPDases, EC 3.6.1.5, also known as ectoATPase or apyrase), which are able to hydrolyse ATP and ADP to AMP [9]. These enzymes show widespread distribution in the brain $[37,38]$ and have low micromolar $\mathrm{K}_{\mathrm{m}}$ for ATP and ADP giving rise to rapid and highly effective hydrolysis of ATP in almost all neuronal tissues. In addition to the E-NTPDase family, ATP could also be dephosphorylated by ecto-nucleotide pyrophosphatases (E-NPPs) and by alkaline phosphatases, both having broader substrate specificity, but also widespread tissue distribution [9].

The next step of extracellular inactivation is the hydrolysis of AMP by the ecto-5'-nucleotidase (EC 3.1.3.5) enzyme, which is the rate-limiting step giving rise to the formation of adenosine, which is a new extracellular signal, acting on its own receptors. Ecto-5'-nucleotidase exhibits micromolar $\mathrm{K}_{\mathrm{m}}$ for AMP and is feed-forwardly inhibited by ATP, which results in a delayed, 'burst-like' adenosine production [30]. It is also widely present in the brain, and it is predominantly associated to glial cells [39, 40], although its expression has been also demonstrated in purified nerve terminals [41, 42]. Finally, adenosine, generated by the ecto-5'-nucleotidase, or released on its own right, is then taken up to the nerve terminal by specific nucleoside transporters (see above) and rapidly reincorporated to ATP stores, or deaminated extra- or intracellularly by the adenosine deaminase enzyme. 


\section{Modulation of microglial activation by $\mathrm{P} 2$ receptors}

It has been known for a considerable time that microglial cells respond with both ionotropic and metabotropic actions to ATP application [43-47]. Whereas the activation of ligand-gated $\mathrm{P} 2 \mathrm{X}$ receptors produces depolarization and $\mathrm{Ca}^{2+}$ influx through the receptor-ion channel complex, the stimulation of the $\mathrm{G}$ protein coupled $\mathrm{P} 2 \mathrm{Y}$ receptors elicits hyperpolarization via phospholipase $\mathrm{C}$ (PLC)- and $\mathrm{IP}_{3}$-mediated mobilization of $\mathrm{Ca}^{2+}$ from intracellular stores and subsequent opening of $\mathrm{K}^{+}$channels (Fig. 1) [47]. Now it is confirmed that all members of the $\mathrm{P} 2$ receptor family are expressed on resting and activated microglial cells kept in culture at the mRNA and/or protein level [48, 49].

Among various subtypes of the ionotropic $\mathrm{P} 2$ receptors, the role of $\mathrm{P}_{2} \mathrm{X}_{7}$ receptors in the microglial response is especially well delineated. Within the P2X receptor family, the $\mathrm{P} 2 \mathrm{X}_{7}$ receptor has a distinguished role for several reasons. First, this receptor seems to function only in homooligomeric form, and is activated by relatively high concentrations of ATP. Second, this receptor was also known previously as $\mathrm{P} 2 \mathrm{z}$ receptor, the 'cell death receptor'; its prolonged activation elicits the opening of a transmembrane pore, permeable to large molecular weight molecules up to $800 \mathrm{Da}$, which finally leads to cellular death. Last but not least, in spite of being cloned originally from the rat brain, it was suggested that $\mathrm{P} 2 \mathrm{X}_{7}$ receptors are expressed predominantly on antigen-presenting immune cells and epithelia, and function as immunomodulatory receptors $[50,51]$. Supporting this concept, a wealth of data confirm that $\mathrm{P} 2 \mathrm{X}_{7}$ receptors regulate many aspects of immune response in the periphery [52], but this holds true for microglial activation as well [53].

The presence of the 'pore-forming' ATP receptor on microglial cells has already been described before the molecular identification of $\mathrm{P}_{2} \mathrm{X}_{7}$ receptors $[54,55]$. The expression of $\mathrm{P}_{2} \mathrm{X}_{7}$ receptor transcripts and of the corresponding protein have been confirmed later in both cultured microglial cells $[51,56,57]$ and in situ microglial cells activated following middle cerebral artery occlusion [51].

Primary microglial cultures and immortalized microglial cell lines respond to ATP and 2',3'-O-(4-benzoyl-benzoyl) adenosine $5^{\prime}$-triphosphate (BzATP) application with an inward current $[54,58,59]$, membrane depolarization, a sustained increase in intracellular free $\mathrm{Ca}^{2+}$ [55], the uptake of high molecular weight fluorescent dyes [55, 58], and the secretion of IL- $1 \beta$ upon an LPS stimulus [55, 60, 61], with a pharmacological profile resembling that of $\mathrm{P}_{2} \mathrm{X}_{7}$ receptors. The central role of $\mathrm{P}_{2} \mathrm{X}_{7}$ receptors, as co-stimulators of the posttranslational processing of IL $-1 \beta$ in microglial cells upon LPS challenge has been repeatedly proven $[19,61$,
62]. The mechanism underlying ATP dependent IL-1 $\beta$ maturation and release in this cell type involves an outwardly directed $\mathrm{K}^{+}$conductance and the activation of interleukin-1 convertase enzyme (ICE, also known as caspase 1) responsible for the cleavage of pro-IL1 $\beta$ to the mature, $17-\mathrm{kDa}$ form [61]. This mechanism appears to participate not only in the exogenous but also in the endogenous activation of $\mathrm{P}_{2} \mathrm{X}_{7}$ receptors, since LPS releases ATP from microglial cells, and the $\mathrm{P}_{2} \mathrm{X}_{7}$ receptor selective antagonist oxiATP prevents the LPS-induced IL$1 \beta$ release [19].

Interestingly, ADP and AMP also act as agonists of $\mathrm{P}_{2} \mathrm{X}_{7}$ receptors in microglial cells in terms of membrane currents and LPS induced IL- $1 \beta$ secretion, but only after 'priming' of the cells by ATP challenge [63]. The molecular mechanism underlying the priming effect of ATP could be a reversible conformational change leading to the modification of the agonist binding motif, or the gating properties of the $\mathrm{P} 2 \mathrm{X}_{7}$ receptor, or its activity-dependent phosphorylation. This priming effect, on the other hand, does not extend to the pore-forming property of recombinant and microglial $\mathrm{P} 2 \mathrm{X}_{7}$ receptors [63].

In addition to IL-1 $\beta$, the synthesis and release of other cytokines, are also stimulated by $\mathrm{P}_{2} \mathrm{X}_{7}$ receptor activation in the microglia. Hence, ATP is a full stimulus (i.e., without the requirement of priming by LPS) to induce TNF $\alpha$ production via a $\mathrm{Ca}^{2+}$-dependent, extracellular signal regulated protein kinase $(\mathrm{ERK}) / \mathrm{JNK} / \mathrm{p} 38$ signaling pathway $[64,65]$, although $\mathrm{P} 2$ receptors other than $\mathrm{P} 2 \mathrm{X}_{7}$ may also participate in ATP-induced ERK activation [65]. On the other hand, involvement of $\mathrm{P} 2 \mathrm{X}_{7}$ receptors in the regulation of the production of the antiinflammatory cytokine, interleukin-6 (IL-6) is more controversial. Whereas Inoue et al. [66, 67] reported that ATP-induced IL-6 production is not mediated by $\mathrm{P} 2 \mathrm{X}_{7}$ receptors, a recent study found markedly elevated levels of IL-6 in the inflamed hindpaw of $\mathrm{P} 2 \mathrm{X}_{7}^{-/-}$mice [68], implicating the participation of this receptor in shaping IL-6 levels. Moreover, Rampe et al. [69] reported that $\mathrm{P} 2 \mathrm{X}_{7}$ receptors play a role in the distinct modulation of cytokine secretory pathways not only after LPS, but also upon amyloid beta peptide $(\mathrm{A} \beta)$ pre-activation. Whereas the production of IL$1 \beta, \mathrm{IL}-1 \alpha, \mathrm{TNF} \alpha$ and IL -18 was increased, that of IL -6 , the anti-inflammatory cytokine was attenuated under these conditions, implicating the involvement of $\mathrm{P}_{2} \mathrm{X}_{7}$ receptors in the pathogenesis of Alzheimer's disease [69].

High concentrations of ATP induce inducible nitric oxide synthase (iNOS) mRNA expression and increase nitric oxide (NO) production from rat microglia [70], an effect potentially mediated by $\mathrm{P} 2 \mathrm{X}_{7}$ receptors. In contrast, ATP by itself does not induce iNOS expression, but enhances IFN $\gamma$ induced iNOS expression and subsequent $\mathrm{NO}$ production in the murine BV-2 microglial cell line through an ERK1/2 
and tyrosine kinase mediated pathway [56]. ATP and BzATP also promote the generation of reactive oxygen intermediates (ROI), in particular superoxide, by interacting with $\mathrm{P} 2 \mathrm{X}_{7}$ receptors, in a way depending on extracellular $\mathrm{Ca}^{2+}$ and the $\mathrm{p} 38$ mitogen activated protein kinase (MAPK) pathway [71]. The stimulation of $\mathrm{P} 2 \mathrm{X}_{7}$ receptors elicits a pronounced increase in the secretion of the endocannabinoid, 2-arachydonoylglycerate (2-AG) in primary microglial cell cultures by the activation of diacylglycerol lipase and the simultaneous inhibition of monoacylycerol lipase, the enzyme responsible for endocannabinoid degradation [72]. This mechanism is noteworthy, because endocannabinoids are also recognized as key regulators of microglial activation [73]. Finally, activation of $\mathrm{P} 2 \mathrm{X}_{7}$ receptors by low concentration of agonists stimulates the release of the neuroprotective mediator plasminogen from cultured microglia [74]. Therefore, regulation of the production of putatively protective (plasminogen, $\mathrm{TNF} \alpha, 2-\mathrm{AG}$ ) and harmful (IL- $1 \beta, \mathrm{NO})$ mediators by $\mathrm{P}_{2} \mathrm{X}_{7}$ receptors appears to follow a highly time- and concentration-dependent pattern [67].

In addition to its role to regulate the production of inflammatory mediators, the activation of $\mathrm{P} 2 \mathrm{X}_{7}$ receptors elicits changes in microglia at the transcriptional level; it rapidly activates the transcription factor nuclear factor of activated $\mathrm{T}$ cells (NFAT) in a $\left[\mathrm{Ca}^{2+}\right]_{\mathrm{o}}$-dependent manner [75] as well as causes the nuclear translocation of NF-KB via ROIs and caspase activation leading to the transcription of a subset of NF-KB target genes [76]. The expression of other transcription factors is regulated time-dependently upon $\mathrm{P}_{2} \mathrm{X}_{7}$ receptor activation. While an acute exposition (10 min to $1 \mathrm{~h}$ ) of microglial cells to ATP and BzATP upregulates the production of the inflammation related protein microglial response factor (MRF)-1 [77], long-term $(6 \mathrm{~h})$ exposure suppresses its transcription and synthesis [78]. Moreover, a conditioned medium from cerebellar granule cells undergoing apoptosis also upregulated MRF-1 release in a $\mathrm{P}_{2} \mathrm{X}_{7}$ receptor-mediated manner, indicating that this mechanism plays a role in the neuron-microglia crosstalk during microglial activation in response to apoptotic signals [78].

According to its pore-forming property, the sustained activation of $\mathrm{P} 2 \mathrm{X}_{7}$ receptors leads to cytolysis in an apoptotic fashion in the microglia [57]. The $\mathrm{P} 2 \mathrm{X}_{7}$ receptor-mediated apoptosis involves the activation of the proteolytic pathway of the caspase activation, which leads to nuclear DNA damage, but is not an absolute requirement for the membrane damage and cytolysis; i.e., if caspases are inhibited, cell death proceeds through the necrotic pathway [79]. Nevertheless, the $P 2 X_{7}$ receptor activated IL-1 $\beta$ secretion and cell death, although both processes involve caspases and both are eliminated in $\mathrm{P} 2 \mathrm{X}_{7}^{-\gamma-}$ mice, appear to be independent from each other [62].
Finally, $\mathrm{P} 2 \mathrm{X}_{7}$ receptor activation also plays an important role in $\mathrm{Ca}^{2+}$ signaling between astrocytes and microglial cells [11]. Astrocyte populations coordinate their functions via $\mathrm{Ca}^{2+}$ waves, and the spread of the $\mathrm{Ca}^{2+}$ signal is implemented by two ways: an intercellular pathway mediated by gap junctions, and an extracellular pathway mediated by ATP and P2 receptors [80]. Moreover, astrocytes communicate by calcium-mediated signaling not only with each other but also with neighboring cells, including neurons and microglia. Thus, astrocyte-derived ATP activates $\mathrm{P}_{2} \mathrm{X}_{7}$ receptors on microglial cells and elicits $\mathrm{Ca}^{2+}$ signals in the microglia, a process which eventually leads to cytolysis of this cell type [11]. It is interesting to note that $\mathrm{P} 2 \mathrm{X}_{7}$ receptor-activation in astrocytes usually does not lead to cytolysis, whilst the same effect might cause cellular death in microglia. The reason for the different resistance of astrocytes and microglia against the $\mathrm{P} 2 \mathrm{X}_{7}$ receptor mediated cytolysis is unknown.

The widespread and profound effects of $\mathrm{P} 2 \mathrm{X}_{7}$ receptor activation on different aspects of microglial activation implicates the role of these receptors in the pathology of CNS and PNS diseases and provokes their applicability as therapeutic targets. Indeed, rapidly emerging knowledge supports such a role, in particular the demonstration of (1) the activity-dependent expression of $\mathrm{P} 2 \mathrm{X}_{7}$ receptors under pathological conditions, and (2) the protective role of $\mathrm{P}_{2} \mathrm{X}_{7}$ receptor ligands in animal disease models. The diseases, in which microglial $\mathrm{P} 2 \mathrm{X}_{7}$ receptors may play either a harmful or protective function include neurodegenerative and neuroinflammatory diseases, such as ischemia-reperfusion and traumatic injury, Alzheimer's disease, sclerosis multiplex, neuro- and retinopathies. In fact, the upregulation of microglial $\mathrm{P}_{2} \mathrm{X}_{7}$ receptors has been observed in several pathological models, including in vivo ischemia [81], a transgenic model of Alzheimer's disease [71], as well as in human tissue samples obtained from patients suffering in proliferative vitreoretinopathy [82], and sensory nerve injury [68].

The first study showing an upregulation of $\mathrm{P} 2 \mathrm{X}_{7}$ receptors in the brain was that of Collo et al. [51], who found an increased immunostaining for $\mathrm{P}_{2} \mathrm{X}_{7}$ receptors in activated microglial cells of the zona penumbra in the middle cerebral artery occlusion (MCAO) model. The microglial upregulation of $\mathrm{P} 2 \mathrm{X}_{7}$ receptors in response to oxygen deprivation has also been documented in the retinal microglia [83]. However, the ischemia-induced upregulation of $\mathrm{P} 2 \mathrm{X}_{7}$ receptors appears in different cell types in a temporally distinct manner. In a more recent study, an early ( 1 day after MCAO occlusion) upregulation of the $\mathrm{P}_{2} \mathrm{X}_{7}$ receptor protein was observed in microglial cells, and later (4-7 days after MCAO occlusion), the receptor was also overexpressed in neurons and astrocytes of the periinfarct area in spontaneously hypertensive rats, as revealed by co- 
localization studies with neuronal, astroglial and microglial markers [81]. $\mathrm{P}_{2} \mathrm{X}_{7}$ receptor overexpression is also associated with microglial cells in other pathological models; e.g., $\mathrm{P}_{2} \mathrm{X}_{7}$ receptor immunoreactivity appears to be upregulated around amyloid plaques in activated microglia and astrocytes in the Tg2576 transgenic mice having mutant amyloid precursor protein (APP) [71].

Altogether, these data indicate that the expression of $\mathrm{P}_{2} \mathrm{X}_{7}$ receptors is strongly activity-dependent during pathological situations. Nonetheless, whether the change in their expression pattern and functional responsiveness is a simple adaptive change or plays a more active pathogenetic role, warrants further investigation. It is also a largely open question whether the final outcome of versatile actions mediated by microglial $\mathrm{P} 2 \mathrm{X}_{7}$ receptors is protective or harmful. As an example, $\mathrm{P} 2 \mathrm{X}_{7}$ receptor deficient mice show increased susceptibility to experimental autoimmune encephalomyelitis (EAE), an animal model of sclerosis multiplex [84], which is potentially due to the decreased microglial secretion of the protective endocannabinoid 2-AG [72]. On the other hand, chronic inflammatory and neuropathic pain is almost completely abolished in the same mice line, which is attributed partly to disrupted microglial production of the inflammatory cytokine IL $-1 \beta$ [68]. Here we have to mention than in addition to those present on the surface of microglial cells, $\mathrm{P} 2 \mathrm{X}_{7}$ receptors on other cell types (i.e., on astroglia and neurons) may also contribute to disease pathology.

In addition to $\mathrm{P} 2 \mathrm{X}_{7}$ receptors, other subtypes of the $\mathrm{P} 2$ receptor family, responding to lower concentration of ATP, are also involved in different aspects of microglial activation [85]. Thus, microglial $\mathrm{Ca}^{2+}$ influx could be also initiated by lower agonist concentrations, effects, which are associated to a non- $\mathrm{P} 2 \mathrm{X}_{7}$ ionotropic, probably $\mathrm{P} 2 \mathrm{X}_{4}$ receptor activation, and there is also a metabotropic, $\mathrm{P} 2 \mathrm{Y}$ receptor mediated response [59, 85]. The expression of $\mathrm{P}_{2} \mathrm{X}_{4}$ receptors is enhanced in the spinal cord microglia after peripheral nerve injury [86, 87], and this receptor and the subsequent activation of the p38 MAP kinase pathway, have been shown to be involved in the generation of inflammatory and neuropathic pain [88, 89].

Early studies showed that exposure of microglial cells to ATP leads to the accumulation of immediate early gene products, c-fos, c-jun, junB and TIS11, effects most likely mediated by $\mathrm{P} 2 \mathrm{Y}$ receptor activation [90]. $\mathrm{P}_{2} \mathrm{Y}_{1}$ receptors mediate the inhibition of the LPS induced IL-1 $\beta$, and TNF$\alpha$ production [91]. The level of proinflammatory cytokines therefore seems to be differentially and oppositely regulated by ionotropic and metabotropic P2 receptors. The production of the anti-inflammatory cytokine IL-6 upon LPS challenge is inhibited by $\mathrm{P} 2 \mathrm{Y}$ receptors [91], although the involvement of pertussin toxin insensitive $\mathrm{P} 2 \mathrm{Y}$ receptors in the induction of IL- 6 production has also been reported [66]. In addition, stimulation of a $G_{i}$ protein coupled,
$\mathrm{P}_{2} \mathrm{Y}_{12}$-like receptor induces membrane ruffling and chemotaxis in cultured primary microglia [92]. Finally, a recent study showed that the activation of P2Y but not P2X receptors induces cyclooxigenase-2 (COX-2) expression in the human microglia [93].

In contrast to the plethora of experimental data obtained in glial cells kept in culture, much less data have been accumulated on the role of glial P2 receptors in more integrated systems, where the cell architecture and extracellular environment are retained. Nonselective cationic membrane currents could be recorded from identified resting microglial cells in acute brain slices in response to ATP (1 mM) and BzATP (0.2 mM) application, which presumably reflects the activation of $\mathrm{P}_{2} \mathrm{X}_{7}$ receptors, although the underlying receptor subtype has not been identified pharmacologically [94]. BzATP also activates microglial $\mathrm{P}_{2} \mathrm{X}_{7}$ receptors in the isolated rat inner retina, which leads to the permeabilization of this cell type [95]. Moreover, intrastriatal administration of ATP promotes cell death in the striatum in vivo, which extends to both neurons, astrocytes and microglial cells, as confirmed by immunostaining by cell-type specific markers NeuN, glial fibrillary acidic protein (GFAP) and OX-42, respectively [96]. However, this effect was mimicked by $\alpha, \beta$-methylene-ATP and ATP $\gamma \mathrm{S}$, and antagonized by reactive blue 2 , but not by pyridoxal-phosphate-6-azophenyl-2',4'-disulphonic acid (PPADS), and therefore is mediated by an unidentified subtype of $\mathrm{P} 2$ receptors.

\section{Modulation of microglial activation by adenosine receptors}

Although relatively limited data have been accumulated on the adenosinergic modulation, microglial cells undoubtedly express functional $A_{1}, A_{2 A}$ and $A_{3}$ but not $A_{2 B}$ adenosine receptors [97], which regulate different aspects of the microglial response [98].

The pivotal role of $A_{1}$ adenosine receptors in neuroinflammation is underscored by a recent study showing that $A_{1}$ receptor null mice develop a severe form of experimental autoimmune encephalomyelitis (EAE), which indicates that endogenous adenosine might have a protective role in the defense against this disease [99]. The involvement of endogenous adenosine in the development of the disease is supported by the downregulation of $\mathrm{A}_{1}$ adenosine receptors in microglia of $\mathrm{A}_{1}^{+/+}$mice and by the beneficial effect of caffeine, which upregulates $A_{1}$ receptors and reduces disease severity concomitantly [99]. Although the identification of cellular effects underlying the protective action of endogenous adenosine awaits further investigation, these findings offer a novel opportunity for the treatment of sclerosis multiplex and other neuroinflammatory diseases. 
Activation of $\mathrm{A}_{2 \mathrm{~A}}$ adenosine receptors differentially regulates the transcription and the de novo synthesis of various subtypes of $\mathrm{K}^{+}$channels, via cAMP- and PKCmediated pathways in cultured rat microglial cells; whereas the expression of Kv1.3 type $\mathrm{K}^{+}$channels are enhanced at both the mRNA and the protein level, only the mRNA but not the protein synthesis of ROMK1 channels seems to be regulated by $\mathrm{A}_{2 \mathrm{~A}}$ receptors [100]. This mechanism could participate in the transition of the microglia from the resting state to the activated form, in which the function of $\mathrm{K}^{+}$ channels seems to play a pivotal role [47]. The $\mathrm{A}_{2 \mathrm{~A}}$ receptor agonist CGS21680 also increases the mRNA expression of nerve growth factor (NGF) and promotes the release of the NGF protein [101] as a well as upregulates COX-2 and induces subsequent $\mathrm{PGE}_{2}$ release in rat microglia again by interacting with $\mathrm{A}_{2 \mathrm{~A}}$ receptors and downstream activation of the cAMP pathway [97].

Selective stimulation of $\mathrm{A}_{3}$ adenosine receptors induces p38 and ERK1/2 phosphorylation in primary murine microglia and in the N13 microglial cell line [102, 103]. This effect is mediated by $G_{i}$ protein coupling and the phosphatidylinositol-3'-kinase (PI3K) [103], and is absent in microglial cells derived from $\mathrm{A}_{3}$ receptor deficient transgenic mice [102].

Adenosinergic stimulation also influences the proliferation/survival of microglial cells; however, the clear-cut identity of the underlying receptor subtype involved in these effects is still uncertain. Thus, early studies indicate that only the simultaneous activation of $A_{1}$ and $A_{2 A}$ receptors could promote microglia proliferation, but this action can be prevented by the $\mathrm{A}_{1}$ selective antagonist DPCPX [104]. On the other hand, the adenosine receptor agonist 2-chloroadenosine also induces apoptosis in rat microglial cells; however, the identity of the adenosine receptor responsible for this latter effect remains unknown [105].

\section{Conclusions}

It is now increasingly clear that ATP is one of the key players of microglial activation, which regulates numerous elements of microglial response from membrane potential to long-lasting transcriptional changes and also affects cell survival. Nevertheless, there are a number of aspects which need further investigation. Despite of the wealth of data on ATP mediated signaling obtained in cultured microglia, the present knowledge is poorly extrapolated to in vivo and disease conditions. The pathways of endogenous activation of purine receptors during the microglial response also need to be better explored. Finally, the mechanisms underlying the protective action of adenosine in the process of microglial activation awaits further investigation. The progress along this line is essential for the therapeutic utilization of purinergic signaling system in neurodegenerative diseases.

Acknowledgements This study was supported by grants of the Hungarian Research Foundation (OTKA T037457), the Hungarian Medical Research Council (472/2003: B.S.), the Hungarian Research and Development Fund (NKFP1A/002/2004), the Volkswagen Foundation (I777 854), and the Interdisciplinary Center for Clinical Research at the Medical Faculty of the University of Leipzig (IZKF).

\section{References}

1. Sperlágh B, Vizi ES (1996) Neuronal synthesis, storage and release of ATP. Semin Neurosci 8:175-186

2. Coco S, Calegari F, Pravettoni E et al (2003) Storage and release of ATP from astrocytes in culture. J Biol Chem 278:1354-1362

3. Latini S, Pedata F (2001) Adenosine in the central nervous system: release mechanisms and extracellular concentrations. J Neurochem 79:463-484

4. Sperlagh B, Vizi ES (2000) Regulation of purine release. In: Abbracchio MP, Williams M (eds) Handbook of experimental pharmacology, vol 151. Springer, Berlin Heidelberg New York, pp 179-209

5. Sperlagh B, Kittel A, Lajtha A et al (1995) ATP acts as fast neurotransmitter in rat habenula: neurochemical and enzymecytochemical evidence. Neuroscience 66:915-920

6. Cunha RA, Vizi ES, Ribeiro JA et al (1996) Preferential release of ATP and its extracellular catabolism as a source of adenosine upon high- but not low-frequency stimulation of rat hippocampal slices. J Neurochem 67:2180-2187

7. Wieraszko A, Goldsmith G, Seyfried TN (1989) Stimulationdependent release of adenosine triphosphate from hippocampal slices. Brain Res 485:244-250

8. Braun N, Sevigny J, Robson SC et al (2000) Assignment of ecto-nucleoside triphosphate diphosphohydrolase-1/cd39 expression to microglia and vasculature of the brain. Eur J Neurosci 12:4357-4366

9. Zimmermann H (2000) Extracellular metabolism of ATP and other nucleotides. Naunyn Schmiedebergs Arch Pharmacol 362:299-309

10. Wang X, Arcuino G, Takano T et al (2004) P2X7 receptor inhibition improves recovery after spinal cord injury. Nat Med $10: 821-827$

11. Verderio C, Matteoli M (2001) ATP mediates calcium signaling between astrocytes and microglial cells: modulation by IFN- $\gamma$. J Immunol 166:6383-6391

12. Wang Y, Roman R, Lidofsky SD et al (1996) Autocrine signaling through ATP release represents a novel mechanism for cell volume regulation. Proc Natl Acad Sci USA 93:12020 12025

13. Hagberg H, Andersson P, Lacarewicz J et al (1987) Extracellular adenosine, inosine, hypoxanthine, and xanthine in relation to tissue nucleotides and purines in rat striatum during transient ischemia. J Neurochem 49:227-231

14. Hisanaga K, Onodera H, Kogure K (1986) Changes in levels of purine and pyrimidine nucleotides during acute hypoxia and recovery in neonatal rat brain. J Neurochem 47:1344-1350

15. Juranyi Z, Sperlagh B, Vizi ES (1999) Involvement of P2 purinoceptors and the nitric oxide pathway in $\left[{ }^{3} \mathrm{H}\right]$ purine outflow evoked by short-term hypoxia and hypoglycemia in rat hippocampal slices. Brain Res 823:183-190 
16. Pedata F, Latini S, Pugliese AM et al (1993) Investigations into the adenosine outflow from hippocampal slices evoked by ischemia-like conditions. J Neurochem 61:284-289

17. Lutz PL, Kabler S (1997) Release of adenosine and ATP in the brain of the freshwater turtle (Trachemys scripta) during longterm anoxia. Brain Res 769:281-286

18. Sperlagh B, Hasko G, Nemeth Z et al (1998) ATP released by LPS increases nitric oxide production in raw 264.7 macrophage cell line via P2Z/P2X7 receptors. Neurochem Int 33:209-215

19. Ferrari D, Chiozzi P, Falzoni S et al (1997) Purinergic modulation of interleukin-1 $\beta$ release from microglial cells stimulated with bacterial endotoxin. J Exp Med 185:579-582

20. Filippini A, Taffs RE, Sitkovsky MV (1990) Extracellular ATP in T-lymphocyte activation: possible role in effector functions. Proc Natl Acad Sci USA 87:8267-8271

21. Sperlagh B, Baranyi M, Hasko G et al (2004) Potent effect of interleukin-1 $\beta$ to evoke ATP and adenosine release from rat hippocampal slices. J Neuroimmunol 151:33-39

22. Sperlagh B, Szabo G, Erdelyi F et al (2003) Homo- and heteroexchange of adenine nucleotides and nucleosides in rat hippocampal slices by the nucleoside transport system. Br J Pharmacol 139:623-633

23. al-Awqati Q (1995) Regulation of ion channels by $\mathrm{ABC}$ transporters that secrete ATP. Science 269:805-806

24. Schwiebert EM (1999) ABC transporter-facilitated ATP conductive transport. Am J Physiol 276:C1-C8

25. Ballerini P, Di Iorio P, Ciccarelli R et al (2002) Glial cells express multiple ATP binding cassette proteins which are involved in ATP release. Neuroreport 13:1789-1792

26. Abdipranoto A, Liu GJ, Werry EL et al (2003) Mechanisms of secretion of ATP from cortical astrocytes triggered by uridine triphosphate. Neuroreport 14:2177-2181

27. Darby M, Kuzmiski JB, Panenka W et al (2003) ATP released from astrocytes during swelling activates chloride channels. J Neurophysiol 89:1870-1877

28. Cass CE, Young JD, Baldwin SA et al (1999) Nucleoside transporters of mammalian cells. Pharm Biotechnol 12:313352

29. Thorn JA, Jarvis SM (1996) Adenosine transporters. Gen Pharmacol 27:613-620

30. Cunha RA (2001) Adenosine as a neuromodulator and as a homeostatic regulator in the nervous system: different roles, different sources and different receptors. Neurochem Int 38:107125

31. Stout C, Goodenough DA, Paul DL (2004) Connexins: functions without junctions. Curr Opin Cell Biol 16:507-512

32. Stout CE, Costantin JL, Naus CC et al (2002) Intercellular calcium signaling in astrocytes via ATP release through connexin hemichannels. J Biol Chem 277:10482-10488

33. Bahima L, Aleu J, Elias M et al (2006) Endogenous hemichannels play a role in the release of ATP from Xenopus oocytes. J Cell Physiol 206:95-102

34. Pearson RA, Dale N, Llaudet E et al (2005) ATP released via gap junction hemichannels from the pigment epithelium regulates neural retinal progenitor proliferation. Neuron 46:731-744

35. Gomes P, Srinivas SP, Van Driessche W et al (2005) ATP release through connexin hemichannels in corneal endothelial cells. Invest Ophthalmol Vis Sci 46:1208-1218

36. Cook SP, McCleskey EW (2002) Cell damage excites nociceptors through release of cytosolic ATP. Pain 95:41-47

37. Wang TF, Rosenberg PA, Guidotti G (1997) Characterization of brain ecto-apyrase: evidence for only one ecto-apyrase (CD39) gene. Brain Res Mol Brain Res 47:295-302

38. Wang TF, Guidotti G (1998) Widespread expression of ectoapyrase (CD39) in the central nervous system. Brain Res 790:318-322
39. Grondal EJ, Janetzko A, Zimmermann H (1988) Monospecific antiserum against 5 -nucleotidase from Torpedo electric organ: immunocytochemical distribution of the enzyme and its association with Schwann cell membranes. Neuroscience 24:351-363

40. Schoen SW, Graeber MB, Reddington M et al (1987) Light and electron microscopical immunocytochemistry of 5'-nucleotidase in rat cerebellum. Histochemistry 87:107-113

41. Cunha RA, Sebastiao AM, Ribeiro JA (1992) Ecto-5'-nucleotidase is associated with cholinergic nerve terminals in the hippocampus but not in the cerebral cortex of the rat. J Neurochem 59:657-666

42. James S, Richardson PJ (1993) Production of adenosine from extracellular ATP at the striatal cholinergic synapse. J Neurochem 60:219-227

43. Norenberg W, Langosch JM, Gebicke-Haerter PJ et al (1994) Characterization and possible function of adenosine 5'-triphosphate receptors in activated rat microglia. $\mathrm{Br} \mathrm{J}$ Pharmacol 111:942-950

44. Walz W, Ilschner S, Ohlemeyer C et al (1993) Extracellular ATP activates a cation conductance and a $\mathrm{K}^{+}$conductance in cultured microglial cells from mouse brain. J Neurosci 13:4403-4411

45. Langosch JM, Gebicke-Haerter PJ, Norenberg W et al (1994) Characterization and transduction mechanisms of purinoceptors in activated rat microglia. Br J Pharmacol 113:29-34

46. Norenberg W, Cordes A, Blohbaum G et al (1997) Coexistence of purino- and pyrimidinoceptors on activated rat microglial cells. Br J Pharmacol 121:1087-1098

47. Illes P, Norenberg W, Gebicke-Haerter PJ (1996) Molecular mechanisms of microglial activation. B. Voltage- and purinoceptor-operated channels in microglia. Neurochem Int 29:1324

48. Bianco F, Fumagalli M, Pravettoni E et al (2005) Pathophysiological roles of extracellular nucleotides in glial cells: differential expression of purinergic receptors in resting and activated microglia. Brain Res Brain Res Rev 48:144-156

49. Xiang Z, Burnstock G (2005) Expression of P2X receptors on rat microglial cells during early development. Glia 52:119-126

50. Surprenant A, Rassendren F, Kawashima E et al (1996) The cytolytic P2Z receptor for extracellular ATP identified as a P2X receptor $\left(\mathrm{P} 2 \mathrm{X}_{7}\right)$. Science 272:735-738

51. Collo G, Neidhart S, Kawashima E et al (1997) Tissue distribution of the $\mathrm{P}_{2} \mathrm{X}_{7}$ receptor. Neuropharmacology 36:1277-1283

52. Di Virgilio F, Chiozzi P, Ferrari D et al (2001) Nucleotide receptors: an emerging family of regulatory molecules in blood cells. Blood 97:587-600

53. Di Virgilio F, Sanz JM, Chiozzi P et al (1999) The $\mathrm{P} 2_{\mathrm{Z}} / \mathrm{P} 2 \mathrm{X}_{7}$ receptor of microglial cells: a novel immunomodulatory receptor. Prog Brain Res 120:355-368

54. Haas S, Brockhaus J, Verkhratsky A et al (1996) ATP-induced membrane currents in ameboid microglia acutely isolated from mouse brain slices. Neuroscience 75:257-261

55. Ferrari D, Villalba M, Chiozzi P et al (1996) Mouse microglial cells express a plasma membrane pore gated by extracellular ATP. J Immunol 156:1531-1539

56. Gendron FP, Chalimoniuk M, Strosznajder J et al (2003) P2X7 nucleotide receptor activation enhances IFN $\gamma$-induced type II nitric oxide synthase activity in BV-2 microglial cells. J Neurochem 87:344-352

57. Ferrari D, Chiozzi P, Falzoni S et al (1997) ATP-mediated cytotoxicity in microglial cells. Neuropharmacology 36:12951301

58. Chessell IP, Michel AD, Humphrey PP (1997) Properties of the pore-forming $\mathrm{P}_{2} \mathrm{X}_{7}$ purinoceptor in mouse NTW8 microglial cells. Br J Pharmacol 121:1429-1437 
59. Visentin S, Renzi M, Frank C et al (1999) Two different ionotropic receptors are activated by ATP in rat microglia. J Physiol 519:723-736

60. Ferrari D, Chiozzi P, Falzoni S et al (1997) Extracellular ATP triggers IL-1 beta release by activating the purinergic $\mathrm{P} 2 \mathrm{Z}$ receptor of human macrophages. J Immunol 159:14511458

61. Sanz JM, Di Virgilio F (2000) Kinetics and mechanism of ATPdependent IL $-1 \beta$ release from microglial cells. J Immunol 164:4893-4898

62. Brough D, Le Feuvre RA, Iwakura Y et al (2002) Purinergic $\left(\mathrm{P} 2 \mathrm{X}_{7}\right)$ receptor activation of microglia induces cell death via an interleukin-1-independent mechanism. Mol Cell Neurosci 19:272-280

63. Chakfe Y, Seguin R, Antel, JP et al (2002) ADP and AMP induce interleukin1- $\beta$ release from microglial cells through activation of ATP-primed $\mathrm{P}_{2} \mathrm{X}_{7}$ receptor channels. J Neurosci 22:3061-3069

64. Hide I, Tanaka M, Inoue A et al (2000) Extracellular ATP triggers tumor necrosis factor- $\alpha$ release from rat microglia. $\mathrm{J}$ Neurochem 75:965-972

65. Suzuki T, Hide I, Ido K et al (2004) Production and release of neuroprotective tumor necrosis factor by $\mathrm{P}_{2} \mathrm{X}_{7}$ receptor-activated microglia. J Neurosci 24:1-7

66. Shigemoto-Mogami Y, Koizumi S, Tsuda M et al (2001) Mechanisms underlying extracellular ATP-evoked interleukin-6 release in mouse microglial cell line, MG-5. J Neurochem 78:1339-1349

67. Inoue K (2002) Microglial activation by purines and pyrimidines. Glia 40:156-163

68. Chessell IP, Hatcher JP, Bountra C et al (2005) Disruption of the $\mathrm{P} 2 \mathrm{X}_{7}$ purinoceptor gene abolishes chronic inflammatory and neuropathic pain. Pain 114:386-396

69. Rampe D, Wang L, Ringheim GE (2004) $\mathrm{P} 2 \mathrm{X}_{7}$ receptor modulation of $\beta$-amyloid- and LPS-induced cytokine secretion from human macrophages and microglia. J Neuroimmunol 147:56-61

70. Ohtani Y, Minami M, Satoh M (2000) Expression of inducible nitric oxide synthase mRNA and production of nitric oxide are induced by adenosine triphosphate in cultured rat microglia. Neurosci Lett 293:72-74

71. Parvathenani LK, Tertyshnikova S, Greco CR et al (2003) P2X mediates superoxide production in primary microglia and is upregulated in a transgenic mouse model of Alzheimer's disease. J Biol Chem 278:13309-13317

72. Witting A, Walter L, Wacker J et al (2004) P2X7 receptors control 2-arachidonoylglycerol production by microglial cells. Proc Natl Acad Sci USA 101:3214-3219

73. Cabral GA, Marciano-Cabral F (2005) Cannabinoid receptors in microglia of the central nervous system: immune functional relevance. J Leukoc Biol 78:1192-1197

74. Inoue K, Nakajima K, Morimoto T et al (1998) ATP stimulation of $\mathrm{Ca}^{2+}$-dependent plasminogen release from cultured microglia. Br J Pharmacol 123:1304-1310

75. Ferrari D, Stroh C, Schulze-Osthoff K (1999) $\mathrm{P} 2 \mathrm{X}_{7} / \mathrm{P} 2_{\mathrm{Z}}$ purinoreceptor-mediated activation of transcription factor NFAT in microglial cells. J Biol Chem 274:13205-13210

76. Ferrari D, Wesselborg S, Bauer MK et al (1997) Extracellular ATP activates transcription factor NF- $\mathrm{KB}$ through the $\mathrm{P} 2_{\mathrm{Z}}$ purinoreceptor by selectively targeting NF-kB p65. J Cell Biol 139:1635-1643

77. Kaya N, Tanaka S, Koike T (2002) ATP selectively suppresses the synthesis of the inflammatory protein microglial response factor (MRF)-1 through $\mathrm{Ca}^{2+}$ influx via $\mathrm{P} 2 \mathrm{X} 7$ receptors in cultured microglia. Brain Res 952:86-97
78. Tanaka S, Koike T (2002) Selective inflammatory stimulations enhance release of microglial response factor (MRF)-1 from cultured microglia. Glia 40:360-371

79. Ferrari D, Los M, Bauer MK et al (1999) $\mathrm{P} 2_{\mathrm{Z}}$ purinoreceptor ligation induces activation of caspases with distinct roles in apoptotic and necrotic alterations of cell death. FEBS Lett 447:71-75

80. Guthrie PB, Knappenberger J, Segal M et al (1999) ATP released from astrocytes mediates glial calcium waves. J Neurosci 19:520-528

81. Franke H, Gunther A, Grosche J et al (2004) $\mathrm{P} 2 \mathrm{X}_{7}$ receptor expression after ischemia in the cerebral cortex of rats. J Neuropathol Exp Neurol 63:686-699

82. Bringmann A, Pannicke T, Moll V et al (2001) Upregulation of $\mathrm{P}_{2} \mathrm{X}_{7}$ receptor currents in Muller glial cells during proliferative vitreoretinopathy. Invest Ophthalmol Vis Sci 42:860-867

83. Morigiwa K, Quan M, Murakami M et al (2000) P2 Purinoceptor expression and functional changes of hypoxia-activated cultured rat retinal microglia. Neurosci Lett 282:153-156

84. Chen I, Raine CS, Brosnan C (2005) Mice with a non-functional $\mathrm{P} 2 \mathrm{X}_{7}$ receptor are more susceptible to experimental autoimmune encephalomyelitis than WT controls. Society Neuroscience Abstracts 902.1

85. McLarnon JG (2005) Purinergic mediated changes in $\mathrm{Ca}^{2+}$ mobilization and functional responses in microglia: effects of low levels of ATP. J Neurosci Res 81:349-3456

86. Guo LH, Trautmann K, Schluesener HJ (2005) Expression of $\mathrm{P} 2 \mathrm{X}_{4}$ receptor by lesional activated microglia during formalininduced inflammatory pain. J Neuroimmunol 163:120-127

87. Schwab JM, Guo L, Schluesener HJ (2005) Spinal cord injury induces early and persistent lesional $\mathrm{P} 2 \mathrm{X}_{4}$ receptor expression. J Neuroimmunol 163:185-189

88. Tsuda M, Shigemoto-Mogami Y, Koizumi S et al (2003) P2X receptors induced in spinal microglia gate tactile allodynia after nerve injury. Nature 424:778-783

89. Inoue K, Tsuda M, Koizumi S (2004) ATP- and adenosinemediated signaling in the central nervous system: chronic pain and microglia: involvement of the ATP receptor $\mathrm{P}_{2} \mathrm{X}_{4}$. J Pharmacol Sci 94:112-114

90. Priller J, Haas CA, Reddington M et al (1995) Calcitonin generelated peptide and ATP induce immediate early gene expression in cultured rat microglial cells. Glia 15:447-457

91. Ogata T, Chuai M, Morino T et al (2003) Adenosine triphosphate inhibits cytokine release from lipopolysaccharide-activated microglia via P2Y receptors. Brain Res 981:174-183

92. Honda SY, Sasaki K, Ohsawa et al (2001) Extracellular ATP or ADP induce chemotaxis of cultured microglia through $\mathrm{G}_{\mathrm{i} / \mathrm{o}^{-}}$ coupled P2Y receptors. J Neurosci 21:1975-1982

93. Choi HB, Hong SH, Ryu JK et al (2003) Differential activation of subtype purinergic receptors modulates $\mathrm{Ca}^{2+}$ mobilization and COX-2 in human microglia. Glia 43:95-103

94. Boucsein C, Zacharias R, Farber K et al (2003) Purinergic receptors on microglial cells: functional expression in acute brain slices and modulation of microglial activation in vitro. Eur $\mathrm{J}$ Neurosci 17:2267-2276

95. Innocenti B, Pfeiffer S, Zrenner E et al (2004) ATP-induced nonneuronal cell permeabilization in the rat inner retina. J Neurosci 24:8577-8583

96. Ryu JK, Kim J, Choi SH et al (2002) ATP-induced in vivo neurotoxicity in the rat striatum via P2 receptors. Neuroreport 13:1611-1615

97. Fiebich BL, Biber K, Gyufko K et al (1996) Adenosine $A_{2 b}$ receptors mediate an increase in interleukin (IL)-6 mRNA and IL -6 protein synthesis in human astroglioma cells. J Neurochem 66:1426-1431 
98. Hasko G, Pacher P, Vizi ES et al (2005) Adenosine receptor signaling in the brain immune system. Trends Pharmacol Sci 26:511-516

99. Tsutsui S, Schnermann J, Noorbakhsh F et al (2004) A1 adenosine receptor upregulation and activation attenuates neuroinflammation and demyelination in a model of multiple sclerosis. J Neurosci 24:1521-1529

100. Kust BM, Biber K, van Calker D et al (1999) Regulation of $\mathrm{K}^{+}$ channel mRNA expression by stimulation of adenosine $\mathrm{A}_{2 \mathrm{~A}^{-}}$ receptors in cultured rat microglia. Glia 25:120-130

101. Heese K, Fiebich BL, Bauer J et al (1997) Nerve growth factor (NGF) expression in rat microglia is induced by adenosine $\mathrm{A}_{2 \mathrm{a}}$ receptors. Neurosci Lett 231:83-86
102. Hammarberg C, Schulte G, Fredholm BB (2003) Evidence for functional adenosine $\mathrm{A}_{3}$ receptors in microglia cells. J Neurochem 86:1051-1054

103. Hammarberg C, Fredholm BB, Schulte G (2004) Adenosine A3 receptor-mediated regulation of $\mathrm{p} 38$ and extracellular-regulated kinase ERK1/2 via phosphatidylinositol-3'-kinase. Biochem Pharmacol 67:129-134

104. Gebicke-Haerter PJ, Christoffel F, Timmer J et al (1996) Both adenosine $\mathrm{A}_{1}$ - and $\mathrm{A}_{2}$-receptors are required to stimulate microglial proliferation. Neurochem Int 29:37-42

105. Ogata T, Schubert P (1996) Programmed cell death in rat microglia is controlled by extracellular adenosine. Neurosci Lett 218:91-94 